\title{
Lüürilisuse ja autobiograafilisuse konflikt
}

\author{
JOOSEP SUSI
}

Mõne aasta eest märkis lürikoloog Dieter Burdorf, et isegi kui luuletus kätkeb selgeid autobiograafilisi komponente, on empiiriline autor ja verbaalselt moodustatud mina sootuks erinevad. Ta väidab, et luule autobiograafiline lugemine on küll võimalik, aga see muudab luuletuse pigem dokumendiks kui ilukirjanduslikuks teoseks. (Burdorf 2017: 23) Selline provokatiivsevõitu seisukoht võib tuua kaasa - igati õigustatult - mitmesuguseid küsitavusi. Esmalt jääb häguseks, mida peetakse silmas luule autobiograafilise lugemise all. Ilmselt on tegemist võrdlemisi intuitiivse ja lihtsustatud määratlusega olukorrale, kui luuletuses esinevaid elemente samastatakse empiirilise autori kaudu referentidega, misläbi nõrgeneb luuletuse autonoomsus. Teisalt käsitleb Burdorf kaht kategooriat - autobiograafilist lugemist ja luulet -, mis näivad tema väites teineteist välistavat. Autobiograafiline luule on aga täiesti olemas ning tegemist pole pelga dokumentatsiooniga, vaid sageli poeetiliselt laetud kvaliteetsete ilukirjanduslike tekstidega. Näiteks Tõnu Õnnepalu päevikuvormis luulekogu „Kevad ja suvi ja” (2009) sisaldab sedavõrd palju äratuntavaid autobiograafilisi elemente, et oleks narr nende referentsiaalsuse kohale tekitada pimetähni nõue. Liiati on ilmunud omajagu tõsiselt võetavaid kirjandusteoreetilisi uurimusi, mis vaatlevad ühtaegu ni i tekstivälise aegruumi ja konkreetsete referentide avaldumist tekstipinnal ku i ka luuletuste poeetilisi külgi ja mõju. ${ }^{1}$

Burdorfi väljaütlemine on küsitavustest hoolimata tõukeks siinsele metateoreetilisele arutlusele lüürilisuse ja autobiograafilisuse konfliktsusest. Keskendudes kitsamalt „lüürilise subjekti” kategooriale, tajub Burdorf ilmselt ohtu, mis kerkib autobiograafilistes lugemistes sageli esile: (lüüriline) luuletus taandatakse pelgalt tegelikkuse dokumentatsiooniks, poeetika nihkub tagaplaanile. Jurilotmanlikult lähenedes võiks väita, et teisest mudelsüsteemi käsitletakse esmase modelleeriva süsteemina. Teisisõnu, lugedes (lüürilist) luuletust autobiograafiliselt, tekib oht lükata kõrvale nii teksti luulelisus kui ka lüürilisus. ${ }^{2}$ Kusjuures selline lugemisstrateegia tõukub paljuski just lüüriliste tekstide traditsioonilistest omadustest. Mitmed lüürika tunnusjooned - iseäranis subjektiivsus (keskendumine valdavalt tundeilmale, emotsioonidele ja mõtetele), nõrk narratiivsus (ei kehtestata loomaailma) ning monoloo-

\footnotetext{
${ }^{1}$ Eesti kirjandusteaduses on viimasel kümnendil neist vahest kõige olulisemad Brita Meltsi uurimused kirjanduslikest omailmadest (nt Melts 2016), mis kätkevad ka luulevaatlusi, ning Maarja Hollo käsitlused Bernard Kangrost (nt Hollo 2016).

${ }^{2}$ Siinkohal on tarvilik teha täpsustus. Burdorf ei erista teineteisest - sarnaselt paljude mainekate lürikoloogidega - küll lüürikat ja luulet, ent vaatleb subjektsuse küsimust just lüüriliste luuletuste kontekstis. Lüürilisuse ja luule eristus on siinses artiklis oluline: seadmata kahtluse alla autobiograafilise luule võimalikkust, vaatlen lähemalt tunnusjooni, mis on omased just lüürilisele luulele ja loovad tugeva lüürilisuse. Seega ei tule vaatluse alla ei lüüriline proosa (kuigi paljud esilekerkivad tendentsid ilmnevad ka seal) ega jutustav luule.
} 
gilisus ja vähene vahendatus (jutustaja instantsi puudumine, ainsuse esimese isiku perspektiiv) - loovad soodsa pinnase lugemisviisile, mis käsitleb lüürilisi tekste aprioorselt omaeluloolistena.

Arusaam lüürilisest luulest kui aksiomaatiliselt usaldusväärsest žanrist toob kergesti kaasa tekstielementide ja nende n-ö tavategelikkuses esinevate referentide samastamise, ja seda peaaegu klassikalises philippelejeune'likus vaimus: lugejad oleksid justkui loomuldasa sõlminud luuletajaga autobiograafilise lepingu, mis põhineb empiirilist autorit, lüürilist subjekti ja lausujat identsena käsitleval lugemisstrateegial (vt Lejeune 2010). Olgu siinkohal toodud üks sellekohane näide. ${ }^{3}$ Elo Viidingu luulekogus „Teatud erandid” (2003) ilmunud poeemi „Ühele hälele” eksplitsiitse adressaadi referendiks on Juhan Viiding. ${ }^{4}$ Luulekogu retseptsioonis peegeldub see, mida Burdorf pidas silmas luuletuse dokumendiks muutumise all. Poeemi kohta on Jan Kaus väitnud: „Luuletuse käigus peab ka kõige tõrkuvam eesti lugeja võtma omaks tõsiasja, et „isa” all ei peeta silmas mõnd üldist printsiipi, vaid üht konkreetset inimest, Juhan Viidingut" (2004: 80). Teisisõnu väidab Kaus, et luuletuse „Ühele häälele” omadused ei ilmne mitte üksnes tekstipinnal, vaid sõltuvad lugeja kontekstuaalsetest, paratekstuaalsetest ja arhitekstuaalsetest teadmistest. Sarnast väidab Mati Unt: „[---] „Ühele häälele” [---] moodustab kogu tegeliku salajase dokumendi” (2004). Kuivõrd „Ühele häälele” adressaadi referent on kultuurilooliselt sümboolne, määratleb tegelik isik poeemi lugemisstrateegia, mistõttu puudub retseptsioonis pea täielikult luuletuse poeetiline analüüs, (auto)biograafiline lugemine tühistab teksti poeetilise mõõtme. Luuletust käsitletakse kui empiirilise autori dokumentaalsetel sündmustel põhinevat pöördumist (vt ka Mihkelev 2004; Ürt 2004), ent poeemi hüperboolne, performatiivsuse tasand, temporaalne võttestik ja mitmekesine apostroofiga mängimine jääb tähelepanuta. Metakriitilisteski seisukohavõttudes osutati, kuivõrd vähe keskendutakse retseptsioonis luulekogule endale (vt nt Eesmaa 2004; Vaher 2004). Paiguti läks kriitika veelgi kaugemale: Andres Langemets keskendub pea eranditult paratekstuaalsetele küsimustele, kusjuures selle asemel et eritleda isikute kujutamist luuletustes, hakkab ta muljetama tegelaste referentidest, poeemi autobiograafiline mõõde muudab ka arvustuse n-ö autobiograafiliseks (2004: 460). Seda, kuidas tekstiväline mõõde halvab luuletuse eritlust, võiks iseloomustada Tiit Hennoste väljaütlemine, et Viidingu „isast ja ilmast” luuletuse „äärmist traagikat täis passaaže analüüsida ei tahaks. Mõjuv." (2004: 407)

Küllap ütleb kirjeldatud retseptsioonipilt nii mõndagi ka eesti (luule)tõlgenduskultuuri kohta, ${ }^{5}$ aga iseäranis lüürilise luule vastuvõtus kipuvad selged autobiograafilised elemendid toimima nii jõuliselt, et muule justkui tähelepanu enam ei jätkugi.

\footnotetext{
${ }^{3}$ Sarnaseid näiteid võiks tuua palju, iseäranis autoritelt, kes kasutavad palju tegelikke elemente näiteks jääb kriitikaväljal märkamatuks Peeter Sauteri luuletuskogude poeetiline tugevus, kuna empiirilise autori kuju ja tema varasem proosalooming määravad lugemisstrateegia.

${ }^{4}$ Selliseid isa poole pöördumisi võiks nimetada omaette teemapõhiseks alažanriks: meenuvad näiteks Franz Kafka „Kiri isale”, Jaan Kaplinski „Isale” ja Beebilõusta pala „Isale”.

${ }^{5}$ Mitut puhku on ses küsimuses sõna võtnud Cornelius Hasselblatt. Näiteks Elo Viidingu raamatu „Püha Maama” kohta väidab ta nõnda: „Suurepärane novellikogu, millest üht-teist kindlasti tasuks tõlkida. Mida aga tegi eesti kriitika: vaatas kõigepealt, kui palju selles kogumikus on jälgi autori isast. Milleks? Ma ei ole sugugi kindel, kas see aitab meid kirjanduse mõistmisel ja hindamisel." (2015: 69)
} 
Siinses käsitluses ei ole keskmes aga üksnes retseptsioonitasand, vaid just põhjused, mis sellise vastuvõtu tingivad (peale lüürika eeltoodud tunnuste). Võtan vaatluse alla viis lüürilise luule tunnusjoont, mille kaudu uurin, kuidas lüürilisus mõjutab autobiograafilisi elemente, mil moel referentsiaalsus teiseneb lüürilises aegruumis ning milline on referentsiaalsuse ja autoreferentsiaalsuse pingeväli. Sellest tõukuvalt esitan kaks vastassuunalist uurimisküsimust: kuidas mõjutavad autobiograafilised elemendid lüürilisust ja kuidas mõjutab lüürilisus luuletuste autobiograafilist materjali?

Juhtumianalüüsides vaatlen luuletusi, mille tekstisisesed ja/või -välised näitajad tõukavad looma sildu lüürilise teksti ja n-ö tavategelikkuse vahel. Näiteks on osutatud empiirilisele autorile (Jaan Kaplinski, Andrus Kasemaa, Hasso Krull) või žanrimääratlusega rõhutatud empiirilise autori tähtsust (Mats Traat). Just sellistes juhtumites ilmneb, miks ei ole mõistlik piirduda lüürika eritluses autobiograafilise lugemisviisiga, olgugi et mitmed žanritunnused tõukavad selle poole (valdavalt puuduvad tekstis ka signaalid, et representatsiooni ja representeeritava vahel oleksid ontoloogilised erinevused) ja otsesed elemendid (nt autori nime kasutamine, kultuuriliselt tuntud inimestele või sündmustele osutamine) võimendavad seda veelgi. On ju ilmne, et igasugused sellised allusioonid ja faktilised elemendid tekitavad kiusatust lugeda luuletusi n-ö tavategelikkust kujutavate tekstidena ning otsida kokkulangevusi (Hühn 2014: 163). ${ }^{6}$

\section{Lüürilisus ja autobiograafilisus}

Olgugi et autobiograafilisus (või omaeluloolisus) haakub tugevasti lüürilise luule olemusega, pole seda kitsamalt lüürilisuse tunnusjoonte kontekstis eriti käsitletud. Autobiograafilisus tuuakse lüürikateoorias mängu pigem teiste kontseptsioonide varjus ((mitte)fiktsioonilisus, metaluule, lüüriline subjekt, subjektiivsus jne) ja sedagi peamiselt faktilise referentsiaalsuse tasandil. Lähenen siinses arutluses autobiograafilisusele just lürikoloogilisest vaatepunktist, et läbi valgustada kahe keskse kategooria - lüürilisuse ja autobiograafilisuse - üldine ja skemaatiline pingeväli. Sellelt positsioonilt võiks autobiograafilisuse all lihtsustatult silmas pidada luuletusest väljapoole suunatust empiirilise autori kaudu.

Ühes vähestest põhjalikumatest selleteemalistest uurimustest väidab narratoloog Stefan Kjerkegaard, et „autobiograafilise lüürilise luule juured on tüüpiliselt poeedi elu sündmustes, aga nende esitamine lüürilise luulena teisendab neid mõnevõrra” (2014: 185). ${ }^{7}$ Ühelt poolt - nagu eelnevalt mainitud - loovad lüürilise luule usaldus-

\footnotetext{
${ }^{6}$ Leidub muidugi autoreid, kes teadlikult ja pidevalt kasutavad faktilise ja lüürilise materjali vahelist pingevälja. Säärane maskimäng ja autorikuvandi teadlik loomine võimendus eesti luules iseäranis 1980. aastate lõpus ja 1990. aastate alguses. Seesama tendents oli esil ka nullindate luules (näiteks Kelly Turk ja Kaur Riismaa), kus sageli võeti lähtekohaks mõni stereotüüpne perspektiiv. Näiteks Kristiina Ehini lüürilistes tekstides mängib siiani rolli (teadlikult konstrueeritud) autorikuvand.

${ }^{7}$ Kjerkegaardi sõnastust võiks täpsustada. Küsimus pole selles, nagu lüürilise luuletuse tõttu muutuksid poeedi elus toimunud sündmused (ehkki mingil äraspidisel moel võib juhtuda sedagi), aga nende sündmuste laad erineb nende kujutamise laadist. Selline arusaam on omane
} 
väärsuse mitmed žanri loomupärased omadused, samal ajal töötavad teised niisama tuumsed tunnusjooned autobiograafilisusele vastu. Mõeldes näiteks Paul de Mani arusaamale autobiograafiast kui igas tekstis mingil moel olemasolevast lugemisviisist, võiks väita, et just lüürilise luule sisekaemuslikkusel ja vähesel deiktilisel konkreetsusel on tugev potentsiaal toimida lugemisprotsessis autobiograafilisena (vt de Man 1979). Kjerkegaard väidab aga, et lüürilises aegruumis teiseneb autobiograafiline materjal kvalitatiivselt ja sellelt lähtekohalt edasi liikudes võib näha, kuidas seesama autobiograafilisus muutub lüürilisust lõhkudes ise lüürilisemaks.

Toon välja viis külgnevat ja omavahel põimuvat lüürilisele luulele omast kategooriat, mis muudavad autobiograafilise materjali omadusi ja mille puudumine nõrgestab oluliselt luule lüürilisust. Tuginen siin paljuski Jonathan Culleri 2015. aastal ilmunud uurimusele „Theory of the Lyric” (vt Culler 2017).

1) Lüüriline a e g. Lüürilist temporaalsust võiks iseloomustada kahe erinevalt toimiva, aga tihtipeale samaaegselt esineva oleviku kaudu. Esiteks: „Lüürika eripäraks näib olevat katse luua mulje, et midagi toimub praegu, diskursuse olevikuajas" (Culler 2017: 37). Tegu on nn lausumisolevikuga (ehk diskursuseajaga): see on „ebamäärane praegu”, mis kordub iga kord, kui luuletust loetakse (Culler 2017: 294-295). Teisalt on lüüriline aeg seotud asjaoluga, et lüürikal puudub enamasti ajadeiktiline konkreetsus, ${ }^{8}$ presentatsioon on justkui ajatus olevikus, ajaülene, väljendades üldiseid, abstraktseid tõekspidamisi. Sedakaudu lahutatakse autobiograafiline materjal referentsiaalsest konkreetsusest, piiritletud aegruumis toimunud sündmus paigutatakse deiktilisse ebamäärasusse ja seotakse lausumisolevikuga. Ja teisipidi: kindel ajaline referent lõhub lüürilist aega, nõrgestab lausumisolevikku ja atemporaalsuse konstrueerimist.

2) I m m e r s i o o n (sukeldumine). Peale ajadeiksise on lüürilises luules määratlematu ka kohadeiksis. See toob kaasa lugeja sukeldumise (re)presenteeritu südamikku. Kuna deiktiline konkreetsus on lüürikas madal, haaravad lugejad n-ö tühja deiksise, olles justkui ise toimuva tunnistajad, mis annab võimaluse isikliku tõlgendamisega ehitada kasinast taustsüsteemist üles terviklik aegruum. Seejuures on oluline ka empiirilise lausuja ja lüürilise subjekti suhe. Nagu Culler (2017: 107) on tabavalt kirjeldanud, siis on see küll lähedane, aga rangelt määratlematu ja mitte kunagi kattuv (kattuvuse korral poleks luuletus enam tugeva lüürilisusega). Just see alatine määratlematus on tarvilik, et lugejale jääks võimalus asetuda mina positsioonile. Kui tekst suunab lugejat aga samastama empiirilist autorit ja lausujat, kaob kiiresti ka sukeldumisvõimalus.

3) Perform atiivs u s. Lüürika niivõrd ei representeeri sündmusi, kui on ise sündmus (Culler 2017: 35). Tugev enesele osutavus toob kaasa olukorra, kus tähen-

\footnotetext{
laiemalt luule autobiograafilisele käsitlusele: jälgitakse, kuidas tekstiväliste elementide poeetiline väljendusviis annab edasi näiteks üldisi arusaamu. Ei maksa arvata, et autobiograafilised uurimused käsitlevad ilukirjanduslikke tekste pelgalt dokumentidena ja jätavad tähelepanuta poeetilise väljendusviisi.

${ }^{8}$ Terminoloogiliselt toetun siin samuti Cullerile. Märt Väljataga on lüürilise aegruumi eripära kirjeldamiseks kasutanud Werner Wolfile tuginedes mõistet absoluutsus: „Werner Wolf kasutab seda sõna etümoloogilises tähenduses „lahtisõlmitus”: luuletused on oma lausumiskontekstist ja reaalsusest lahti päästetud, lüürilised lausungid on osutusseosest vabad" (Väljataga 2013: 260-261).
} 
dus põhineb paljuski sellel, mida luuletus t e e b: „Luuletus ei taha meile lihtsalt öelda, mis tunne on midagi sellist kogeda, ta tahab taasluua sellise kogemuse, nagu midagi oleks kunagi juhtunud ja juhtub luuletuses taas" (Kjerkegaard 2014: 193). Lüüriline luule põhineb otseselt tegutsemisega seotud diskursusel: ühelt poolt on selle eesmärk väita midagi kindlat reaalse maailma kohta või seda otseselt muuta (veenda kedagi, puudutada hingeliselt, kinnitada väärtushoiakuid vms) (Culler 2017: 128), teisalt on lüüriline luule suunatud lausumisele (esitusele/ettekandmisele). Lüürika performatiivsuse parimaks näiteks on alažanrid, nagu hümn või palve. Niisiis on lüürika performatiivsus seotud iseenese kehtestamisega lüürilisena, mistõttu taanduvad faktilised ning autobiograafilised elemendid lüürilise luuletuse kui sündmuse ees: referentsiaalsus muutub ebaoluliseks, sest igasugused referendid on justkui uuesti ellu kutsutud ja allutatud parasjagu toimuva kogemisele, mis selle teksti paradoksaalsel moel ka ise kehtestab. Dominique Rabaté (2017: 95) on selle sõnastanud nii: objektid säilitavad küll oma referentsiaalse väärtuse, mis on aga loomuldasa allutatud meetrumi ja rütmi tekkimiseks vajalikele keelelistele operatsioonidele, poeetilisele väljendusviisile.

4) Hü p e r b o ols u s. Lüüriline aeg tingib võimendunud hüperboolsuse. Kuigi lüüriline luule kujutab enamasti subjektiivseid tundeid ja emotsioone, ei ole tegemist otsese tunnete väljendamisega, vaid muu hulgas üldise seisukohaga tegelikkuse või inimese kui niisuguse kohta - lüürika on samal ajal nii rangelt isiklik kui ka rangelt üldine. Mingis mõttes taotleb sedasama igasugune autobiograafiline kirjutis (ka Elo Viidingu poeem hõlmab üldisi arusaamu isa ja tütre suhetest), aga lüürilises luules on see võimendunud: subjektiivne ja singulaarne (kindla referendita), mis põimub lugejatasandiga, kattub üldisega, on lüürilise aegruumi kaudu alati ja kõigiti toimiv. Autobiograafilised elemendid lüürilises luules evivad automaatselt ka laiemat metonüümilist ja hüperboolset potentsiaali. Vastasel korral poleks tegemist lüürilise luuletusega: kui näiteks Juhan Liivi „Lumehelbeke” kirjeldaks kindlat aegruumi ja kindlaid tundeid, ei oleks n-ö reaalsusest lahti sõlmitud (vt Väljataga 2013: 260), nõrgeneks kohemaid lüürilisus.

5) Apostro ofsus. Apostroof kui kõnekujund on poeetiline pöördumine: pöördutakse abstraktse isiku või nähtuse poole, mis tegelikult ei saa vastata. ${ }^{9}$ Apostroof pole kunagi otsene, vaid vähemasti kolmesuunaline (nn triangulatsioon), sisaldades nii tekstisisest (eksplitsiitset) adressaati, lugejat kui ka lüürilist subjekti. Apostroofi (ja igasuguse lüürilise adressaadi) kolmesuunalist dünaamikat võiks laiendada ka autobiograafilisele materjalile: see on osa nii lausujast kui ka väljendatud adressaadist, aga samal ajal on see suunatud lugejate poole. Näiteks nõrgeneb poeemis „Ühele häälele” lüürilisus muu hulgas seetõttu, et eksplitsiitne adressaat on sedavõrd selge, et lõhub pöördumise kolmesuunalisuse ega toimi niivõrd enam lüürilist subjektsust loova funktsioonina.

\footnotetext{
${ }^{9}$ Lüürilise luule esimesed kuulsamad tekstid (näiteks Sappho säilinud luulekatked) põhinevad paljuski apostroofsusel ja sellega külgnevatel tunnustel. Culler rõhutas juba 1970. aastate teises pooles, et luule koosneb kahest poolusest, narratiivsest ja apostroofsest, kusjuures lüürika on „apostroofsuse triumf” (Culler 1981: 149).
} 


\section{Fiktsioonilisus ja faktilisus: kolm lähenemist ${ }^{10}$}

Olen juba mitut puhku kasutanud terminit faktiline, mida üldiselt autobiograafiakäsitlustes ei esine. Küll aga on lürikoloogias viimastel kümnenditel pööratud tähelepanu fiktsioonilisuse-faktilisuse teljele. Lüürilise luule suhe nende kategooriatega määratleb otsustavalt ka autobiograafilise materjali suhte referentsiaalsega. Narratoloog Peter Hühni eritluses seostub see dihhotoomia suhtega tavategelikkusesse: „---] kas representatsioon viitab millelegi, mis eksisteerib representatsiooniaktist sõltumata, või kas representeeritav on (täielikult või valdavalt) välja mõeldud, fiktiivne ja semiootilise representatsiooni loodud" (2014: 156). Enamasti polemiseeritakse säärase küsimuse üle narratiivsemate tekstidega seoses, kuivõrd lüürikas loomaailma enamasti ei teki ning sündmused ja tegelased on pigem mentaalset, emotsionaalset laadi ja/või tugeva abstraktsusastmega. Küll aga on selge, et narratiivseid, faktilisi ja fiktiivseid elemente kätkeb ka lüüriline luule.

Fiktsioonilisuse-faktilisuse teljele lähenetakse (lüürilise) luule kontekstis laias laastus kolme moodi ja eri lähenemised muudavad otsustavalt ka arusaama, kuidas peaks käsitlema autobiograafilist materjali. Esimest lähenemist esindab Hühn, kes väidab, et poeetilised tunnused võivad kaasa tuua mitteautentsuse ja kunstlikkuse mulje (ehk faktilisuse nõrgenemise), aga samal ajal mõjutada lugejaid emotsionaalselt, mõjuda emotsionaalselt tõepärasena ja sedakaudu lugeja hoiakuid kinnistada (faktilisust tugevdada) (2014: 160). Hühni sõnul on lüürilise luule žanrikonventsioon seotud fiktsioonilisuse-faktilisuse telje ambivalentsusega ja selle keskseks tekstisiseseks tunnuseks on alati olnud rohke ainsuse esimese isiku kasutamine (2014: 157-159). ${ }^{11}$ Esimene lähenemine mõistab niisiis fiktsioonilisust ja faktilisust sisuliselt lugemisstrateegilise küsimusena, mille aga jätavad teksti enda objektiivsed omadused lahtiseks. Samal ajal on Hühni seisukohalt oluline dominant - see, kumb kaksikjaotuse poolus on (tekstis ja/või lugemisprotsessis) ülekaalus. Lüürilise luule autobiograafilisuse kontekstis võib seda pidada määravaks. Kui domineerib fiktsioonilisus, ei ole mõtet kõneleda ka omaeluloolisusest: igasugune autobiograafiline element on allutatud väljamõeldisele.

Teine levinud - ja fiktsiooniuurimustes valdav - suund on pidada lüürilist luulet loomuldasa mittefiktsiooniliseks ja mittemimeetiliseks. Lürikoloogias on selle silmapaistvaim apologeet Culler, kes on veendunud, et lüürilisus ei põhine fiktsioonilise ruumi kehtestamisel, vaid eeskätt üldiste abstraktsete teemade väljendamisel:

\footnotetext{
${ }^{10}$ Esmapilgul võiks fiktsioonilisuse-faktilisuse küsimus juhatada Aare Pilve (nt 2010, 2011) ja Märt Väljataga (2009) uurimusteni. Siinses artiklis lähenen küsimusele aga rangelt lürikoloogianarratoloogia kontekstis. Pealegi käsitleb Pilv valdavalt hoopis teisi ja laiemaid teoreetilisi aspekte. Väljataga mainib korduvalt, et kirjandusteaduses jäetakse lüüriline luule enamasti fiktsiooni vallast kõrvale.

${ }^{11}$ Hühn jätab aga tähelepanuta lüürilise luule immersiooni eripära. Nimelt toovad madal deiktiline konkreetsus ja rituaalsed tunnused kaasa muu hulgas selle, et lugeja võtab endale lausuja positsiooni. Näiteks kõige traditsioonilisemates armastusluuletustes ei samastu lugeja niivõrd adressaadi, kuivõrd just lüürilise lausujaga. Siin on aga oluline, et kui lausuja positsioonile nihkub empiiriline autor, kerkib esile tõeväärtuse küsimus (tekst ei ole enam üldiselt subjektiivne, nagu lüürilisele luulele omane, vaid seotud empiirilise autori subjektiivsusega).
} 
lüüriline luule „väidab midagi meie maailma kohta” (2017: 32). Lüürilises luules võivad esineda küll fiktsioonilised ja faktilised elemendid (osutused tegelikele või väljamõeldud isikutele ja ajaloolistele sündmustele vms), aga need on kõik allutatud lüürilisele väljendusele, keelelisele sündmusele - keeleline akt lõhub faktilisust ja fiktsioonilisust. Küsimus pole enam selles, kas osutatud elemendid on tegelikkusega mingil moel vastavuses, vaid selles, et lüüriline väljendus on olemuslikult tavategelikkusega otseses suhtes: igasugused fiktsioonilised ja faktilised elemendid lüürilises luules toimivad tegeliku maailma muutmise teenistuses. Culleri väidetest võib minna aga sammukese kaugemale: kuivõrd autobiograafiline/faktiline materjal on allutatud lüürilisele performatiivsusele, erinevad selle omadused referentide tunnustest. Ja teisipidi, fiktsioonilised ja faktilised elemendid lõhuvad lüürilist aegruumi.

Culleri lähenemine on toonud kaasa poleemikat. Ühelt poolt on mitmed lürikoloogia valda kuuluvad katsed piiritleda või prototüübisemantiliselt määratleda lüürilist luulet võtnud aluseks just lüürika fiktsioonilisuse (arusaam, millega siinkirjutaja ei nõustu). Teiselt poolt on iseäranis tugev vastuseis tajutav narratoloogilistes käsitlustes. Eri vastuväiteid ühendab retseptsioonitasandile keskendumine. Ka Hühn (2014: 160) väidab, et see, „millele luuletus viitab, realiseerub tegelikult ja faktiliselt lugeja peas" ning et lüürika on žanr, mille faktilisus sõltub nii kultuurilistest, sotsiaalsetest kui ka puhtindividuaalsetest teguritest, kogemustest, vaadetest. Selliste vastuväidete impulss peitub luulele omases tugevas fragmentaarsuses:

Luuletused sisaldavad enamasti mõtete, tunnete, tajude, emotsioonide, mälestuste, kujutluste järgnevust või üldisemalt kogemusi, mis on esitatud tüüpiliselt lühendatud, kokku pressitud, kompaktses vormis, n-ö mikronarratiividena, usaldades lünkade täitmisel ja puuduvate seoste loomisel lugeja narratiivset kompetentsi ja maailmakogemust. (Hühn 2014: 155)

Üks jõulisemaid vastuväiteid arusaamale lüürikast kui mittefiktsioonilisest žanrist on narratoloog Eva Zettelmanni (2017) artikkel, mis käsitleb lüürilise luule fiktsioonilist mõõdet just lugeja perspektiivist ${ }^{12}$ ja mis esindab fiktsioonilisuse-faktilisuse küsimuses n-ö kolmandat suunda. Zettelmann väidab, et lugedes hakatakse ikkagi ette kujutama kognitiivseid pilte fiktsioonilisest maailmast, fragmentaarsed elemendid sünteesitakse terviklikuks loomaailmaks, kognitiivsete skriptide ja freimide abil tehakse leksikaalsetest üksustest ülekanne võimalikesse maailmadesse. Teisisõnu, semantiliste ühikute ja tavaelu vaheliste sildade loomine ning kirjanduslike skriptide kontseptualiseerimine võib toimuda lugeja peas. Sellisel juhul kehtestatakse fiktsiooniline maailm, vaatamata minimaalsele taustsüsteemile: „Kognitiivsetes rekonstruktsioonides püüdlevad lugejad tekstis loodud kindla ruumilise, emotsionaalse ja ideoloogilise vaatepunkti poole" (Zettelmann 2017: 138-140). Tõsi, need loomaailmad erinevad tüüpilise narratiivse teksti põhjal konstrueeritud fiktsioonilistest universumitest: need on fragmentaarsed, ebamäärased, „potentsiaalselt

${ }^{12}$ Zettelmann esitab oma nägemuse küll paljuski vastuväitena Cullerile, aga nende arusaamade lahknevus on seotud sellega, et Culler arutleb tekstikeskselt, Zettelmann retseptsioonitasandil. Kusjuures Culler on lüürikateoorias lugeja institutsiooni väärtustamise üks eestkõnelejaid. 
lõputud" (isiklik panus on märgatavalt suurem kui narratiivsete tekstide puhul), skemaatilised jne (Zettelmann 2017: 140-142).

Zettelmanni (2017: 136) sõnul võiks selline lähenemine pakkuda alternatiivi igasugustele (auto)biograafilistele käsitlustele. Kui lüüriline luule on suunatud lausumisele ja põhineb lugeja enda sisendil, siis lugeja kujutlusvõime abil kehtestatud fiktsiooniline ruum ei luba lüürika autobiograafilisi elemente käsitleda autobiograafiliselt, sest lugemisprotsessis tepitakse need vastuvõtja kujutlusvõimega ja muudetakse n-ö fiktsiooniliseks. Zettelmann näib väitvat ka midagi veel üldisemat: lüürilise luule lugemine läheb paratamatult lahku teksti enda tunnustest, lugemisprotsessis konkretiseeritakse ruumiline määratlematus ning mittefiktsiooniline fiktsionaliseeritakse.

Fiktsioonilisuse-faktilisuse telje kolm suunda haakuvad otseselt lüürilise luule autobiograafilisuse küsimusega. Kui siinkohal mõista faktilisust ja autobiograafilisust sünonüümidena, siis Hühni järgi on lüüriliste tekstide autobiograafilisus loomuldasa ambivalentne ning tegemist on paljuski lugemisstrateegilise küsimusega: lugeja võib käsitleda teksti kas autobiograafilise või lüürilisena. ${ }^{13}$ Culler väidab, et autobiograafilisus ei puutu üldse asjasse, sest kui tegemist on lüürilise luuletusega, on tekst ametis iseenda kehtestamisega sündmusena (autobiograafilisus on allutatud lüürilisusele). Zettelmann aga nihkub retseptsioonitasandile ja väidab, et kuna lugemisprotsessis konstrueeritakse ikkagi fiktsiooniline mõõde, siis fiktsionaliseerub ka autobiograafiline materjal, mis põhineb omakorda suures osas lugeja enda sidusa maailma loomise panusel. Need kolm suunda ei välista üksteist ning nendel põhinevad paljuski järgnevad juhtumianalüüsid. Kusjuures kõiki kolme faktilisuse ja fiktsioonilisuse kategooriatele lähenemise viisi võiks iseloomustada autobiograafilisuse ja lüürilisuse vastandamine: Hühn väidab, et nende vahel tuleb lugejal valida, Culler vastandab mõlemad kategooriad lüürilisusele ning Zettelmanni arusaama kohaselt muutub autobiograafiline materjal vastuvõtutasandil lugeja kaudu fiktsiooniliseks.

\section{Kas Hasso on ikka Hasso? Kas Kasemaa on Kasemaa?}

Võtan vaatluse alla neli luuletust, mille tekstisisesed elemendid viitavad selgelt empiirilisele autorile ja/või tema tundeilmale. Jälgin autobiograafiliste elementide ja lüürilisuse toimimist, võttes aluseks eeltoodud viis lüürika tunnust (lüüriline aeg, immersioon, performatiivsus, hüperboolsus ja apostroofsus).

\footnotetext{
${ }^{13}$ Tekstiväliste teadmiste, nt autobiograafilise materjali kasutamine tõlgendusprotsessis võib põhjalikult muuta teksti semantikat. Näiteks Juhan Liivi luuletuses „Eile nägin ma Eestimaad” pole otseselt viidatud, mis aastaaega kirjeldatakse. Loodud meeleolu osutab vähemasti siinkirjutaja lugemiskogemuses sügisele või suvele. Kui aga teada, et Liiv kirjutas teksti jaanuarikuu alguses, muutub kogu luuletuse tonaalsus, atmosfäär. Semiootiliselt lähenedes on see denotatiivselt väljajättev lugemisstrateegia. Kersti Merilaasi 1937. aastal kirjutatud armastusluuletus „August” kirjeldab armastajaid suveõhtul. Teadmine, et pealkiri viitab peale suvekuu ka empiirilise autori abikaasale (August Sangale), ei tühista esimest n-ö süütut lugemisviisi. Tegemist on denotatiivselt alternatiivse lugemisstrateegiaga: teadmine empiirilise autori elust lisab ühe tähendustasandi, aga ei tõrju välja teisi.
} 
Andrus Kasemaa luuletuses „Kingitus riigilt” kogust „Lagunemine” (2009) rõhutab faktilisust - täpsemalt seda, et nii mainitud sündmus kui ka sellest johtuvad tunded/mõtted on olemas ka ilma (re)presentatsioonita - luuletuse lõpuosas toodud isikukood ning selle omistamine vaesele luuletajale.

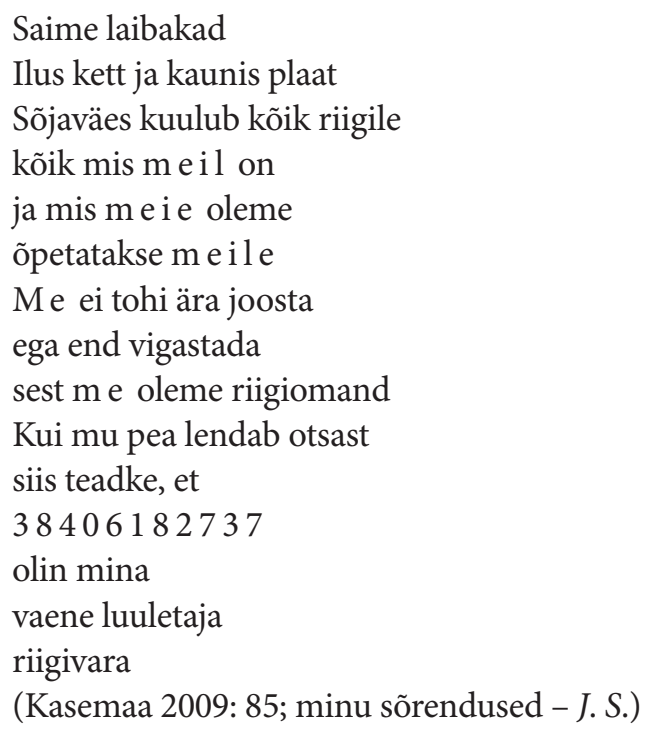

Temporaalsete teisenemiste toel moodustub diskursusetasandil narratiiv. Esimesed kaks rida on seotud konkreetse - aga ajaliselt piiritlemata - minevikusündmusega, kus lausuja-tegelane saab sõjaväes kätte identifitseerimiskoodiga metallplaadi (nn laibaka). Järgmised seitse rida nihkuvad aga ajatusse olevikku, väljendavad üldisi arusaamu üksikisiku ja riigi vahelistest suhetest; lausuja-tegelase paigutumist kõikide teiste indiviidide sekka rõhutatakse mitmuse esimese isiku asesõna kasutamisega. Viimased kuus rida nihkuvad aga tulevikku, lausumisolevikust vaadatakse edasi, kirjeldatakse võimalikku maailma (milles lausuja sureb) ning osutatakse sedakaudu tagasi luuletuse algusele. Kusjuures viimane osa on sõnastatud apostroofselt: samal ajal pöördutakse nii riigi kui ka lugejate poole, kes tulevikus surnud vaest luuletajat peaksid identifitseerima. Tuleviku ja lausumisoleviku põimumine võimendab viimases osas narratiivsust ja fiktsioonilisust. ${ }^{14}$

Kasemaa luuletuse vältel jõutakse pikema atemporaalse sisekaemuse toel ühest üksikust situatsioonist potentsiaalsesse loomaailma. Ühelt poolt pole mõtet kahelda, et lausujaga samastatav isikukood viitab otseselt teksti kirjutanud poeedile. Siin toimub aga autobiograafiliste elementide kvalitatiivne teisenemine: teksti hüperboolsust rõhutab keskmise osa ajatu representatsioon, mille toel isikukoodist saab pigem

\footnotetext{
${ }^{14}$ Heather Dubrow kasutab sellise tulevase situatsiooni kirjeldamiseks mõistet anticipatory amalgam, mis haakub mõistega the disnarrated (sündmused, mida ei juhtu, aga millele siiski viidatakse). Anticipatory amalgam on olukord, kus kombineeritakse narratiivi ja lüürika omadused, kuna osutatakse millelegi, mis ei ole juhtunud. See on lüürika ja narratiivi lüürilisel refleksioonil põhinev hübriidvorm. (Dubrow 2006) Sedasama nähtust võib nimetada ka lihtsalt kontrafaktuaalsuseks.
} 
individuaalsuse bürokraatlikuks taandumise rõhutus. Liiati tuuakse eelviimases reas sisse loovinimese tasand. Nii leiab aset indiviidi mõtete ja potentsiaalse tuleviku võimendamine sel moel, et referendi omadused ei evi enam tähtsust, need on muutunud funktsiooniks, mis avab loovinimese individuaalsuse olemusliku vastuolu riigi ja sõjaväe institutsionaalsusega. Selline seaduspära iseloomustab lüürilist luulet laiemaltki: autobiograafilised elemendid kaotavad lüürilise temporaalsuse, hüperboolsuse ja apostroofsuse kontekstis referentsiaalse konkreetsuse. Samal ajal toimub ka vastupidine protsess: kindla isikukoodiga luuakse lugemisstrateegia, mis toob tekstiruumi empiirilise autori. Sellisel juhul nõrgeneb teksti lüürilisus: lugeja sukeldumine lüürilise aegruumi südamikku raskeneb, aegruumiline määratlematus nõrgeneb (aegruum saab empiirilise autori kaudu konkreetsema taustsüsteemi), hüperboolsust võimendava keskmise osa meievorm muutub kitsamaks (iseäranis ridades 7-9).

Tekstisiseseid osutusi empiirilisele autorile kohtab omajagu ka Jaan Kaplinski luules. Vaatlen põgusalt teksti, mis algab tsitaadiga ühest arvamusavaldusest Kaplinski luule kvaliteetide ning tema tunnustamise vastuolu kohta.

„Niisugune öeldamatusega võrduv kõikeöeldavus ning ükskõikmisöeldavus kui põhimõtteliselt ebakommunikatiivne keelekontseptsioon on J. Kaplinski viimase aja luulest teinud „(aru)saamatuste” allika ning autorist endast kõrbelauliku, kelle tunnustamise ja mõistetavuse vahe on jõudmas kriitilise piirini."

Linnar Priimägi

Tunnustamise ja mõistetavuse vahe kriitilisel piiril, kord siin- kord sealpool kõigub J. K. sügistuules nagu kuiv angervaksa vars. Kui ta kirjutab, siis teispool arusaadavuse piiri.

Kui teeb putru, peseb pesu või peseb pead, siis arvatavasti siinpool. Piiri lähedal muutuvad mõõdud, kaugused ja väärtused. Asjad lähevad üksteisega segi, seep ei vahuta, vesi keeb toatemperatuuril, jäätis ei sula, nirk on suvelgi valge ja kunst tundub nii kunstlik, et J. K. tahab kirjutada end kunstist lahti, kirjutada end endast lahti. Kõik ta ümber saab aina kaugemaks - lehed, lapsed, raamatud, kõik saab vähem tema omaks; kauge on aina selgem ja teravam, lähedane aga saab uduseks, kirjad vaevuloetavaks, kõige lähem hajub hoopis ja kui igaks juhuks sirutad sõrme ja katsud kohta ruumis, mis peaks olema sinu keha või hing, pole kummastki vähematki järel. Arvatavasti on luule oma eesmärgi saavutanud. (Kaplinski 1991: 20) 
Jällegi ei ole mingit põhjust kahelda, et initsiaalid J. K. viitavad Jaan Kaplinskile ja et Linnar Priimägi on nõndaviisi tema kohta kirjutanud või vähemasti võiks seda nii teha (tõeväärtus pole antud juhul oluline). Arvestades pööret Kaplinski loomingus 1980. aastatel, mis tõi kaasa tema luuletuste üha enam autobiograafilises võtmes lugemise, on põhjust tõmmata paralleele ka tekstis manifesteeritud kunstikäsitluse ja empiirilise autori esteetiliste eelistuste/tõekspidamiste vahel. Ometi töötab tekst ise sellele lähenemisele vastu.

Esmajoones juba sedaviisi, et J. K. on asetatud tegelase positsioonile, teda vaadatakse valdavalt kõrvalt: referent ja representatsioon lahutatakse eksplitsiitselt, empiirilise autori ja lausuja-tegelase kõrval esineb ka tegelane, kelle referendiks võib pidada empiirilist autorit, aga kes toimib muu hulgas maskina, mille tagant paljastuvad laiemad tõekspidamised. Iseäranis oluline on tegelase J. K. lokatsioon: ta paigutatakse paradoksaalsele üleminekualale, kus asjade omadused hakkavad teisenema, muutuvad tavategelikkuse mõistes vastupidisteks. J. K. paikneb sellises kujundlikus ja ajatus piiritsoonis, mille taga virvendab luule või kunst. Märgiline on pööre luuletuse lõpuosas (neli viimast rida), kus ainsuse kolmas isik asendub ainsuse teise isikuga (mida võib samastada nii J. K. kui ka lugejaga, samuti laiendada teksti ülesehitavaks funktsiooniks): ühtäkki pöördutakse abstraktse adressaadi poole. Ühtekokku pole J. K. enam mitte Jaan Kaplinski, vaid luuletuses tervikut kokku viiv funktsioon, mille kaudu avaldub elu ja kunsti, argise ja kunstlikkuse konfliktsus. Just selline ambivalentsus muudab lüürilisuse tugevamaks: initsiaalid/nimi sõlmitakse eri võtetega lahti referentsiaalsest konkreetsusest.

Huvitav on aga küsimus, kuidas toimib teksti sissejuhatus. Sedagi võib nimetada ühelt poolt faktiliseks materjaliks, teisalt on siin peidus ka laiem otsustamatus: kas sissejuhatus allub luuletuse poeetilisele mõõtmele või mitte? Teisiti sõnastades: mil moel erineb lüürilises luuletuses sissejuhatusena esitatud tekstilõigu tähendus selle täpselt samal kujul ajakirjanduses esinevast referendist (või intertekstist/tsitaadist)? Ja teisipidi, kuidas seesama lõik teisendab luuletuse nn põhiosa? Ühelt poolt kehtestatakse lausuja-tegelase kaudu tegelase J. K. ja tegelase Linnar Priimäe vaheline monoloogiline, st ühe lausuja perspektiivist esitatud dialoog. Kusjuures sarnane dialoogiline dünaamika on lüürikatraditsioonis sage algusest peale. Nii toimib sissejuhatus isoleeritud taustsüsteemina. Teisest küljest ei saa jätta tähelepanuta tõsiasja, et põhiteksti esimene rida on sissejuhatusega samasuguses stiiliregistris ning avab ja laiendab seda, mõtleb sellest edasi. Priimäe teksti viimane kõrvallause läheb sujuvalt üle põhiteksti esimeseks reaks - sissejuhatus justkui lõimitakse põhiteksti. Sõltumata sellest, kummast lugemisviisist kinni haarata, saab sissejuhatusest lüürilise subjekti konstrueerimise alusmaterjal, evides sedakaudu lüürilist mõõdet.

Lüüriline põhitekst toob kaasa aga veel mitu aspekti, mis muudavad sissejuhatuse omadusi. Toon neist välja kolm. Esmalt võiks taas osutada hüperboolsusele. Kuivõrd Kaplinski tekstis peitub tugev manifestatsioon, teiseneb märgatavalt ka luuletuse algus: luuletaja ja kriitiku dialoogis või ühises tekstiloomes ei ole sissejuhatus enam pelgalt arvamusavaldus Kaplinski luule kohta, vaid Kaplinski luulemanifestiga omamoodi konfliktis ja sümbioosis olev manifest, mis väljendab väga selgelt üldisi printsiipe ega kuulu enam rangelt Linnar Priimäele, vaid lüürilisele lausujale/lugejale. 
Teiseks näib suisa hämmastav, kui sujuvalt liigutakse teksti vältel sissejuhatusest eemale, samal ajal seda tagasiulatuvalt teisendades. Segunema hakkavad ka stiiliregistrid: Kaplinski luuletuse põhiteksti vältel mängitakse Priimäe tekst semantiliselt ja stilistiliselt ümber, nii et see pole enam kaalutletud esseistlik arvamusavaldus, vaid tugevalt poeetilise ambitsiooniga lõik.

Kolmas aspekt seostub apostroofsuse ja lugeja positsiooniga lüürilises luules. Kui lugeja hõivab nn tühja deiksise, ebamäärase lausujapositsiooni, siis isegi juhul kui mõni lugeja nõustuks Priimäe arvamusavaldusega kriitikaväljal, ei saa ta seda selle luuletuse lugejana teha sellesama lõiguga Kaplinski luuletuses: väärtushinnangud, lüüriline subjekt - mille üks komponente on lugeja - konstrueeritakse kujundliku keelekasutuse kaudu ning nii kehtestub ka tekstisisene poeetilise ruumi tõde. Kui Zettelmannil on õigus, siis konstrueerib lugeja lüürikale omase immersiooni kaudu luuletusest fiktsioonilise maailma - peale juba teksti pinnal kehtestatud fiktsioonilise mõõtme, mis joonistub välja (mikro)narratiivi(de) kaudu -, mille tulemusel muutub ka nn faktiline element (Kaplinskil teksti sissejuhatus) väljamõeldise osaks (säilitades samal ajal referentsiaalse kvaliteedi). Seesama asjaolu iseloomustab igasugust (auto)biograafilist materjali lüürilises luules: omaeluloolised elemendid tepitakse luuletuse väärtussüsteemi, stiili ja semantikaga, mille tõttu suureneb kujutatu ja selle referendi vaheline erinevus; retseptsioonitasandil võimendub ka selgelt autobiograafilise materjali fiktsioonilisus. Võib aga läheneda ka vastupidi: kui luuletuse sissejuhatust käsitleda Priimäele kuuluva faktilise arvamusavaldusena, nõrgenevad vaatluse all olevad lüürilised tunnusjooned, luuletus muutub Kaplinski vastuväiteks konkreetsele seisukohale. Sedakaudu nõrgeneb nii immersioonipotentsiaal (lausujapositsioon on tihedamalt seotud empiirilise autori kuju ja loominguga), aegruumiline ebamäärasus (Priimäe väljaütlemine muudab luule vormis vastuväite ajaliselt täpsemaks), lüürikale omane performatiivsus (luuletus ei taha taasluua kirjeldatut, vaid väljendab kindlaid tõekspidamisi), hüperboolsus (rõhutatult on tegemist Kaplinski vastuväitega Priimäe arvamusavaldusele) ja apostroofsus (keskmesse tõuseb suunatus Priimäe väljaütlemisele). Sellise lähenemisviisi juures ei ole sissejuhatus enam luuletuse loomulik osis.

Kui Kaplinski luuletuses on autorinimelise tegelase lahknemine empiirilisest autorist märgitud ainsuse kolmanda isiku kasutamisega, siis sageli ei ole selline eristus nii selge. Vaatame näiteks Hasso Krulli luuletust kogust „Kandsime redelit kaasas" (2017):

Selline läbitungimatu pimedus, selline pimeduse riit, oi kui tihedalt laotud, seda jätkub terveks talveks, kui ta just ümber ei kuku. Külm talv. Lumi.

Pimeduse halud. „Hasso, siin e majõ e ääres paar kilomeetrit minu majast kasvab üks murdunud ladvaga kask. Võib-olla olen mina ka." (05.03.2008)

Pimeduse halge uuesti riita ei laota, 
neid ei leita enam kunagi, nad on

kadunud pimedusse, ja millega siis kütta?

Tähed paistavad läbi taevatelgi,

siis pole neidki, hahetab, valgeneb juba,

kõik on nii selgesti näha, isegi sinu

kontuurid voodis teki all,

maailma kõige ilusam naine,

näen neid piirjooni, olen

nagu nöörile riputatud maakaart.

(Krull 2017: 16; minu sõrendus - J. S.)

Krulli tekstis ei mängi tõeväärtus taaskord mingit rolli: lugejal pole tarvis pead vaevata küsimusega, kas selline konkreetselt dateeritud sõnum või kõneakt on tegelikkuses sellisel kujul esinenud. Arvestades aga lüürilise luule aksiomaatilist usaldusväärsust, võib seda käsitleda kõneaktina, mis eksisteerib ka väljaspool lüürilist aegruumi (ja lugeja võib seda muidugi ka mitte teha, pidada faktilisena mõjuvat fragmenti puhtakujuliseks väljamõeldiseks). ${ }^{15}$

Jutumärkides pöördumine on adresseeritud tegelasele, kes kannab empiirilise autoriga sama eesnime, ning see pöördumine on määratletud kuupäevaliselt. Rangelt lausumisajas paiknev luuletus tervikuna aga hägustab kuupäeva ajadeiktilist konkreetsust: kuna sel puudub taustsüsteem, võiks tegemist olla ka ükstapuha missuguse teise kuupäevaga, selle põhifunktsioon näib olevat faktilisuse, usaldusväärsuse konstrueerimine üldiselt. Nii võiks mõelda ka igasuguse autobiograafilise elemendi ajadeiktilisest muutusest lüürilises luules: tavategelikkuses esinev spetsiifiline hetk sulandub lüürilisse aega (lausumisolevikku ja atemporaalsusesse). Krulli luuletuses on kõik määrused ilma kindla taustsüsteemita ning aeg ja ruum jäävad rõhutatult üldisteks. Vastassuunaliselt lähenedes: luuletuses pärisnime kasutamine, jutumärkidega tähistatud kõneakt ja konkreetne kuupäev mängivad žanrikonventsioonidega, mistõttu väheneb immersioonipotentsiaal, suureneb vahendatus - nõrgeneb lüürilisus. Viimase kahe reaga suurendatakse aga subjektiivsuse, sissepoole vaatava enesekehtestamise muljet, mis Krulli luulele tüüpiliselt tugevdab just luuletuse lõpus teksti lüürilisust ning teisendab sedakaudu ka kogu varasemat teksti. Nii muutub ka käsitletud tekstiosa paljuski lüürilise subjekti siseilma (re)presentatsioonist johtuvaks elemendiks (tegemist pole väljapoole suunatud osutusega).

Kirjeldamisega paralleelselt viiakse luuletuses läbi kujundi järkjärguline väljatöötamine/ülesehitamine. „Pimeduse riit” ja „pimeduse halud” põimuvad jutumärgistatud kõneakti lausujaga, kes tunneb end kui „üks murdunud ladvaga kask”. Väline ja üldine ning sisemine ja intiimne paigutatakse pidevalt kohakuti, mille kaudu toetab kõneakt mõlemat tasandit: ühtaegu käsitletakse nii välist soojust/kül-

\footnotetext{
${ }^{15}$ Siit võib minna veel kaugemale ja väita, et igasugune (ka varasema informatsiooniga vastuollu minev) fakt on lüürilises aegruumis alati usaldusväärne. Isegi juhul, kui referent ja representeeritu ilmselgelt lahknevad.
} 
must kui ka inimlikku soojust/lähedust. ${ }^{16}$ Taas võib siinkohal üldistada: autobiograafiline materjal evib lüürilises aegruumis kujundlikku potentsiaali, faktilised elemendid justkui tõmbavad endasse erisuguste lause- ja kõnekujundite omadusi, väline osutus on lõpuks allutatud siseilma kujutamisele.

Sarnaselt Kaplinski luuletusega eristub Krulli tekstis fokalisatsiooni muutuse kaudu (või narratiivse tasandi vahetusega) lausuja-tegelane ja tegelane (lahknevad Hasso Krull, tegelane-Hasso ja lausuja-tegelane). Taas on autorinimeline tegelane mask, polüfoonilisuse tekitaja. Kummalisel kombel just faktilisena mõjuva tekstiosa abil lõhutakse singulaarsust, individuaalsust. Enamgi, peale implitsiitse adressaadi kätkeb luuletus veel kolme tüüpi pöördumist: ebamäärase adressaadiga retooriline küsimus („,ja millega siis kütta?”), pöördumine autorinimelise tegelase poole ning luuletuse lõpus esinev pöördumine tüüpilise lüürilise sina poole („kõik on nii selgesti näha, isegi sinu / kontuurid voodis teki all"). Viimane toob sisse aga ambivalentsuse, kuna jääb lahtiseks, kas jutumärkides kõneakt kuulub samale „sinale”. Igasugused paratekstuaalsetena esitatud elemendid paiknevad luuletuses üha vahelduvate ja teisenevate registrite, aga samal ajal püsiva lokaliseerimatuse keskel. Vastuoksuslike kujundite mõjule omaselt ehitatakse kord üles usaldusvärrsuse mulje, teisal jällegi lõhutakse seda, mistõttu muutub võimatuks öelda midagi täpsemalt eri elementide faktilisuse kohta.

Kui eeltoodud tekstides domineeris nõrk narratiivsus, siis Mats Traadi luuletuses „Autobiograafia” joonistub selgelt välja areng/narratiivsus, mille loovad paralleelselt esinevad kliimaks ja antikliimaks:

Laps olin,

kui möödus sõjakolin.

Nooruk olin,

kui tuli traktorikolin.

Mees olin,

kui algas sõnakolin.

Kolin kolina järgi.

Saadaks põrgu kogu värgi,

aga hing on luulehaige.

(Traat 1968: 36)

\footnotetext{
${ }^{16}$ Krulli luuletus on siinkirjeldatust muidugi märgatavalt keerukam. Kujunditasandil joonistub välja mitmeid piiritletud ja ambivalentseid tähenduskihte (nt valguse ja pimeduse, nähtavuse ja nähtamatuse, käsitatavuse ja käsitamatuse dünaamika, samuti paradoksid: kombatamatu kombatavus, maakaardi vaade kontuurile jms). See pole aga siinse arutluse kontekstis esmatähtis.
} 
Inimese bioloogilisi arenguetappe läbiv gradatsioon (laps-nooruk-mees) on kontrastis välist maailma puudutava litootesega (sõda-traktor-sõna). Kusjuures isikliku ja üldise kõrvuti seadmine lõpeb ambivalentselt: „sõnakolin” võib tähistada küll välise telje kõige väiksemat, aga samal ajal kõige väärtuslikumat ja kaalukamat ühikut. Viimast versiooni kinnistab luuletuse lõpp, kus eelnev narratiivsus pööratakse sissepoole vaatava, singulaarse ja isikliku mõõtmega lüürilisuseks. Antud juhul tugevdab viimaste ridade lausumisolevikus pöördumine ka varasema teksti lüürilisust: eelnev on mingis mõttes visuaalne presentatsioon ja siseilma refleksioonile alluv olevikuline mineviku representatsioon. Jällegi võib Traadi tekstis toimuvat laiendada: igasugune (omaelu)loolisus pakitakse kokku lüürilisse aega, see pole enam poeetiline autobiograafia, vaid lüüriline luuletus, mille enesekehtestamiseks kasutatakse faktilisena mõjuvaid elemente. Sellest tekstist johtub ka asjaolu, et tugeva lüürilisuse tagab - erinevalt kolmest eelmisest näiteluuletusest - see, et pealkirjaga postuleeritud žanriootused täidetakse kasinalt e h $\mathrm{k}$ lüüriliselt: autobiograafilisus ei avaldu eksplitsiitselt, puudub igasugune (nt ajaline ja ruumiline) konkreetsus, kusjuures ka pealkiri ei seostu seetõttu otseselt empiirilise autoriga. Võib väljenduda ka nõnda, et luuletuse tugeva lüürilisuse taga on asjaolu, et tekstis puuduvad autobiograafilised komponendid. Muidugi on võimalik luuletust lugeda autobiograafiliselt, seostada ka empiirilise autori eluga, aga sellisel juhul nõrgeneb teksti lüürilisus.

Toodud neli näidet iseloomustavad, kuidas autobiograafiline materjal teiseneb lüürilises kontekstis ja suhestub lüürikale omaste tunnustega. Nii aja- kui ka kohadeiktiline määratlematus hägustab autobiograafiliste elementide aegruumilisi omadusi; lüürilise aja, hüperboolsuse ja apostroofsuse tõttu kaob referentsiaalne konkreetsus; omaeluloolised elemendid põimuvad ka luuletuse väärtussüsteemi, stiili ja semantilise tasandiga. Igasugused omaeluloolised (mikro)narratiivid muutuvad lüürilises luules põhjalikult: need allutatakse lüürilisele ajale, mis toob kaasa autobiograafiliste elementide lahknemise nende referentide ajalistest ja ruumilistest väärtustest. Laiemalt seatakse autobiograafilise materjali faktilisus küsimärgi alla, kusjuures tõlgendustasandil põimub see lugeja kujutlusvõimega ning saab tugeva fiktsioonilise mõõtme. Tugev performatiivsus ja nn rituaalsus toovad kaasa ka selle, et autobiograafiliste elementide tõeväärtus pole enam oluline. Kui käsitleda teksti lüürilisena, on autobiograafiline ja/või faktiline materjal allutatud luuletuse poeetilisele dimensioonile ja teiseneb sellest johtuvalt. Neli luuletust tõestasid ka vastupidist. Autobiograafiline materjal nõrgestab lüürilisust: lüürilise teksti autonoomsus ja performatiivsus nõrgenevad, suureneb aja- ja kohadeiktiline konkreetsus, keskmesse nihkub tõeväärtuse küsimus, väheneb lugeja immersiooni võimalus, teiseneb hüperboolsus ja konkretiseerub adressaat (lõheneb nn kolmesuunalisus).

\section{Lõpetuseks}

Lüürilist luulet loetakse sageli autobiograafilises võtmes. Iseäranis juhul, kui tekst kätkeb äratuntavaid faktilisi/autobiografilisi elemente. Selline lugemisviis on täiesti võimalik ja sageli ka viljakas, nagu on võimalik ja sageli viljakas igasugune 
traditsiooniline autorikeskne lähenemine. Tihtilugu annavad sellised eritlused uusi lähenemisnurki ja avavad empiirilise autori motivatsiooni, tekstiloome impulsse ning uusi tähendustasandeid. Olen siinses artiklis näidanud, mil moel mitmed lüürika prototüüpsed tunnused (vaatlesin neist viit: lüüriline aeg, immersioon, performatiivsus, hüperboolsus ja apostroofsus) teisendavad autobiograafilise materjali kvaliteete. Teisisõnu, autobiograafilisus toimib lüürikas teisiti kui muudes žanrides: autobiograafiline materjal - ja selle autobiograafilisena avaldumine lugemisprotsessis - lõhub poeetilise aegruumi lüürilisust. Kirjeldaksin seda konflikti olukorrana: autobiograafilisus lõhub lüürilisust ja lüürilisus teisendab omakorda elementide autobiograafilisust. Seda protsessi võib kirjeldada skalaarsena: mida autobiograafilisemalt lugeda lüürilist luulet, seda nõrgema lüürilisusega on luuletus, ja vastupidi. See aga - rõhutan taas - ei tähenda sugugi, et lüürilist luulet ei võiks käsitleda autobiograafiliselt.

Esile kerkib paljuski dünaamika, mis sarnaneb igasuguse paratekstuaalse materjali mõjuga lüürikale. Tekstivälised tunnused/tendentsid lõhuvad lüürilist autonoomsust ja nõnda lüürilisus nõrgeneb. Olen varem vaadelnud, kuidas mõjutavad luuletuste kõrval paiknevad fotod lüürilisi tunnusjooni. Ilmneb näiteks, et tihedas vastastikmõjus visuaalse meediumiga nõrgeneb luuletuste lüürilisus, samal ajal kui fotode lüürilisus tugevneb, ning et kaks eri meediumit muudavad teineteist narratiivsemaks (Neier, Susi 2019). Sarnast lüürilisuse nõrgenemist võib täheldada ka olukorras, kus tõlgendusprotsessi hakkavad jõuliselt sekkuma empiirilise autori väljaütlemised kriitikaväljal (Susi 2019). Esitatud põhiväidet võib aga tugevdada ja öelda, et vähemasti lugemisprotsessi silmas pidades ei ole lüüriline luuletus kunagi autobiograafiline: (tugev) lüürilisus ja (tugev) autobiograafilisus on kaks teineteist välistavat lugemisstrateegiat.

Nendest väidetest võiks minna veelgi kaugemale ja postuleerida hoopis vastupidise arusaama, mis ehk avaks lüürika olemust pareminigi: lüüriline luuletus on a priori autobiograafiline. Selline arusaam nõuab aga tekstuaalselt tasandilt liikumist retseptsioonilisele. Lugeja ise haarab lüürilise luuletuse nn tühja deiksise, muutub lüüriliseks subjektiks: lüürilise luuletuse lugemine tähendab, et lugeja kui autor konstrueerib teksti subjektiivsest ja isiklikust materjalist autobiograafilise aegruumi. Tõepoolest, lüüriline luule on ses mõttes a l a t i autobiograafiline.

\section{KIRJANDUS}

Burdorf, Dieter 2017. The I and the others. Articulations of personality and communication structures in the lyric. - Journal of Literary Theory, kd 11, nr 1, lk 22-31.

Culler, Jonathan 1981. The Pursuit of Signs: Semiotics, Literature, Deconstruction. LondonHenley: Routledge \& Kegan Paul.

Culler, Jonathan 2017. Theory of the Lyric. Cambridge (Mass.)-London: Harvard University Press.

de Man, Paul 1979. Autobiography as de-facement. - MLN, kd 94, nr 5, lk 919-930.

Dubrow, Heather 2006. The interplay of narrative and lyric: Competition, cooperation, and the case of the anticipatory amalgam. - Narrative, kd 14, nr 3, lk 254-271. 
Eesmaa, Lauri 2004. Teatud kriitika. - Vihik, nr 9, lk 45-47.

Hasselblatt, Cornelius 2015. Eemalt vaadates. Veerand sajandit eesti kirjandusega. (Studia litteraria Estonica 15.) Toim Arne Merilai, Ele Süvalep. Tartu: Tartu Ülikooli Kirjastus.

Hennoste, Tiit 2004. Kõiki huvitab kõik. See on ajastu programm. Eesti luule 2003. - Looming, nr 3, lk 398-411.

Hollo, Maarja 2016. Romantiline subjekt, mälu ja trauma Bernard Kangro sõjajärgses loomingus. (Dissertationes litterarum et contemplationis comparativae Universitatis Tartuensis 14.) Tartu: Tartu Ülikooli Kirjastus.

Hühn, Peter 2014. The problem of fictionality and factuality in lyric poetry. - Narrative, kd 22, nr 2, lk 155-168.

Kaplinski, Jaan 1991. Tükk elatud elu. Tekste 1986-1989. Tartu: Eesti Kostabi \$elts.

Kasemaa, Andrus 2009. Lagunemine. Tallinn: Eesti Keele Sihtasutus.

Kaus, Jan 2004. Üks hääl. - Vikerkaar, nr 9, lk 75-82.

Kjerkegaard, Stefan 2014. In the waiting room: Narrative in the autobiographical lyric poem, or beginning to think about lyric poetry with narratology. - Narrative, kd 22, nr 2, lk 185-202.

Krull, Hasso 2017. Kandsime redelit kaasas. Tartu: Kaksikhammas.

Langemets, Andres 2004. Teatavaist erandeist. - Looming, nr 3, lk 459-460.

Lejeune, Philippe 2010. Autobiograafiline leping. - Methis. Studia humaniora Estonica, nr 5-6, lk 196-223.

Melts, Brita 2016. Kirjanduslikud omailmad ja nende autobiograafilised lätted. (Dissertationes litterarum et contemplationis comparativae Universitatis Tartuensis 15.) Tartu: Tartu Ülikooli Kirjastus.

Mihkelev, Anneli 2004. Löö puruks kosmos, myyr ja tuum ja mängi kõiki mänge! - Sirp 18. VI, lk 11-12.

Neier, Agnes; Susi, Joosep 2019. Verbaalse ja visuaalse dialoog. Sissejuhatus lüürilise luule ja foto vastastikmõjusse. - Keel ja Kirjandus, nr 6, lk 460-479.

Pilv, Aare 2010. Minakirjutusest. Tõnu Õnnepalu, Mihkel Raua ja Madis Kõivu näitel. Methis. Studia humaniora Estonica, nr 5-6, lk 122-130.

Pilv, Aare 2011. Teese poieetilisest metonüümsuspõhimõttest. - Keel ja Kirjandus, nr 10, lk 721-733.

Rabaté, Dominique 2017. A world of gestures. - Journal of Literary Theory, kd 11, nr 1, lk 89-96.

Susi, Joosep 2019. Kuidas luuletada lugu isa valvsa pilgu all? - Hasso Krulli mõistatus. (Etüüde nüüdiskultuurist 8.) Toim Neeme Lopp. Tallinn: Tallinna Ülikool, Eesti Kunstiakadeemia, lk 45-54.

Zettelmann, Eva 2017. Discordia concors. Immersion and artifice in the lyric. - Journal of Literary Theory, kd 11, nr 1, lk 136-148.

Traat, Mats 1968. Laternad udus. Tallinn: Eesti Raamat.

Unt, Mati 2004. Must päike ja Paulo Coelho. - Sirp 5. III, lk 12.

Vaher, Berk 2004. Viginad ja karjed. - Vikerkaar, nr 6, lk 103-104.

Viiding, Elo 2003. Teatud erandid. Tallinn: Tuum.

Väljataga, Märt 2009. Luule- ja pärislugude eristus teoorias ja praktikas I. - Keel ja Kirjandus, nr 6, lk 401-410. 
Väljataga, Märt 2013. Mis on luule? II. - Keel ja Kirjandus, nr 4, lk 253-268.

Õnnepalu, Tõnu 2009. Kevad ja suvi ja. Tallinn: Varrak.

Ürt, Julius 2004. Vaimueliidi lapsed. - Eesti Päevaleht 30. I.

Joosep Susi (snd 1989), MA, Tartu Ülikooli kultuuriteaduste instituudi nooremteadur (Ülikooli 16, 51014 Tartu); Tallinna Ülikooli kirjandusõpetuse ja eesti kirjanduse nooremlektor, joosep.susi@gmail.com

\section{The conflict between lyric and autobiographical}

Keywords: lyric time, immersion, performativity, hyperbole, apostrophe, fictionality

Several features of lyric poetry - e.g. subjectivity, vague deixis, monologic structure, low mediation, and weak narrativity - provide a good ground for reading lyric texts as a priori reliable and autobiographical. The metatheoretical discussion here takes a lyricological approach to the relationship of referentiality and self-referentiality in lyric poetry with a view to illuminating the general field of tension between the lyric and the autobiographical. The focus of the discussion is on the following five prototypical features of lyric poetry: temporality, immersion, performativity, hyperbole, and apostrophe.

As is proved by case studies, lyric poetry tends to blur the time and space characteristics of autobiographical moments, as far as those are separated from concrete reference. As a result, a specific point in time or space blends into lyric atemporality and sticks together with the uttering present. As for autobiographical material, it is intertwined with the underlying values, figurative system and semantics of the poem; moreover, its authenticity is questioned, thus increasing the probability for the lyric text to be read as fiction. External references are subdued as the focus moves to introspection. The autobiographical element, in turn, undermines lyric by weakening the autonomy and performativity of the lyric text, enhancing the specificity of temporal and spatial deixis, questioning the truth value of the text (lowering its axiomatic reliability), reducing the reader's option for immersion, restricting textual hyperbolicity and concretizing the addressee.

Thus, in lyric poetry autobiographical material functions differently than in other genres. There is an inherent conflict in the field of tension between the lyric and the autobiographical as autobiographical compromises lyric, while lyric, in turn, transforms the autobiographical of certain moments. On receptive level the process can be described as a scalar one, notably, the more autobiographically we read a lyric poem, the weaker its lyricism, and vice versa.

Joosep Susi (b. 1989), MA, University of Tartu, Institute of Cultural Research, Junior Researcher (Ülikooli 16, 51014 Tartu); Tallinn University, Junior Lecturer of Estonian Literature, joosep.susi@gmail.com 